\title{
Ecological and biological characteristics of tree plantings of the Orel SAU arboretum
}

\author{
E.A. Parakhina ${ }^{1, *}$, Zh.G. Silaeva ${ }^{2}$, L.L. Kiseleva ${ }^{3}$, N.N. Chaadaeva ${ }^{3}$, and A.P. Tyapkina ${ }^{4}$ \\ ${ }^{1}$ Peoples' Friendship University of Russia, Department of Geoecology, Moscow, Russia \\ ${ }^{2}$ Orel State Agrarian University named after N.V. Parakhina, Department of Landscape Architecture, \\ Orel, Russia \\ ${ }^{3}$ Orel State University named after I.S. Turgenev, Department of Botany, Physiology and Biochemistry \\ of Plants, Orel, Russia \\ ${ }^{4}$ Orel State University named after I.S. Turgenev, Department of Zoology, Orel, Russia
}

\begin{abstract}
Arboretums are centers of introduction and study of woody plants' ecological and biological characteristics, promising species identification for their subsequent introduction in landscape construction. The dendrological park has conducted studies of both wild and introduced species of woody plants, 117 species in total. The analysis of urban conditions stability and decorativeness of 117 woody plants' species, including wild species, as well as systematic, biomorphological and chorologic analyses were performed. The article provides data on the degree of introduction and winter resistance of 96 trees and shrubs species. According to the results of the study, the list of the wood plants most successfully adapted to urbanized conditions for their further use in the cities of Central Russia considering their features in landscape design was composed.
\end{abstract}

\section{Introduction}

Botanical gardens and arboretums play a huge role in biodiversity preservation and species richness replenishment of regions, in educating the population, studying the adaptive plants' properties in alien natural conditions, assessment of their ecological and decorative qualities, study of the plants' usage possibility, including in landscape construction. After all, plants are the link in human communication with nature. Creating a comfortable urban environment is impossible without a comprehensive study of the ecological plants' properties. Particular attention is always paid to woody plants, because it forms the ecosystems' basis of urbanized territories.

The arboretum of the Orel State Agrarian University named after N.V. Parakhin was established over 20 years ago in 1999 on undeveloped territory to study ecological and phenological features of woody plants in urban environments, identify new promising species and forms of trees and shrubs to be used in various types of landscape compositions, as well as for teaching students specializing in "Landscape Architecture". The total area of the park is 8.7 hectares. [1]

\footnotetext{
${ }^{*}$ Corresponding author: eparachina@yandex.ru
} 
Currently, the arboretum of the Orel State Agrarian University named after N.V. Parakhin possesses significant resources that allow to solve various tasks related to comfortable environment formation, diversity preservation of local natural complexes, attraction of new plant resources, development of modern landscaping principles, improving regional inhabitants' well-being, including increasing the level of environmental education.

For more than twenty years of its existence, the arboretum has undergone various changes - the planning organization changed, new plant species and forms planting, etc. Therefore, the purpose of this work was to sum up the intermediate study results of ecological and ornamental features of woody plants in the urbanized territory.

\section{Material and methods}

Orel climate is moderately continental. According to the temperature regime, the city of Orel is a territory with warm summers and moderately cold winters [2]. According to perennial data, the average annual air temperature is $+5,6^{\circ} \mathrm{C}$. Its maximum is observed in July $\left(+19.3^{\circ} \mathrm{C}\right)$, minimum - in February $\left(-6,7^{\circ} \mathrm{C}\right)[3]$.

Recent years have shown upward changes in temperature regime in both January and July, but July warming is significantly less pronounced. The total period duration with a positive average daily air temperature in the year is $210-220$ days. The period with an average daily temperature above $+5^{\circ} \mathrm{C}$ begins in mid-April and ends in October (175-185 days - a long growing season). The period with a daily temperature above $+10^{\circ} \mathrm{C}$ begins in early May and ends in the third decade of September (135-150 days, short growing season). According to long-term observations, frosts occur in the third decade of September and stop in the first decade of May.

The region has an average of $480-610 \mathrm{~mm}$ of precipitaton. The regime of precipitation is characterized by intra-year unevenness. The precipitation amount of the warm period varies between 393-419 mm, which is about 70\% per annum [2].

The object of the study is the woody plants of the Orel SAU Arboretum.

Identification of wood plantations' species composition was carried out by route method followed by cameral processing of the collected material. Research was carried out in 20192020. In determining species, we relied on various keys including regional [4-10].

Biomorphological analysis of wood plants of the Orel SAU Arboretum was carried out according to the criteria of Sokolov S.Ya., Sviazeva O.A. (1965) [11]:

$\mathrm{D}_{1}$ - first degree tree (height more than $20 \mathrm{~m}$ );

$\mathrm{D}_{2}$ - second degree tree (height 16-20 m);

$\mathrm{D}_{3}$ - third degree tree (height 11-15 m);

$\mathrm{D}_{4}$ - fourth degree tree (height up to $10 \mathrm{~m}$ );

$\mathrm{K}_{1}$ - first degree shrub (height more than $6 \mathrm{~m}$ );

$\mathrm{K}_{2}$ - second degree shrub (height 4-6 m);

$\mathrm{K}_{3}$ - third degree shrub (height 2-4 m);

$\mathrm{To}_{4}$ - fourth degree shrub (height up to $2 \mathrm{~m}$ );

Introduction evaluation was carried out according to Golovach A.G. (1980) with some changes $[12,13]$ :

1 - complete naturalization - the plant is well developed, has a healthy appearance, selfplanting, leaves the culture;

2- good vitality - the plant is well developed, has a healthy appearance, well-developed shoots, buds and leaves, their normal coloration, blooms abundantly or well, bears fruits;

3- satisfactory or average vitality - the overall development of the plant is somewhat weaker, the shoots growth, foliation, flowering and fruiting do not reach maximum;

4- weak vitality - the plant is noticeably weakened, the growth of shoots is insignificant, flowering and fruiting are single or absent; 
5- "excluded species" or species that have only been tested in introduction for a few years and have not yet reached maturity.

The assessment of winter resistance was carried out according to the method of Sokolov S.Ya, Svyazeva O.A. (1965) [11]:

1. the plant is quite winter-resistant;

2. the ends of the plant's shoots freeze;

3. large branches freeze;

4. the entire terrestrial part to the level of snow cover (or soil) freeze;

5. the plant does not overwinter, that is, it is freezing with the root.

The assessment of wood plantings' sanitary condition was performed to determine the tree condition category according to the generally accepted methodology as per the evaluation scale (Rysin et al., 2015) [14]:

Woody plants with no signs of weakening. The crown is thick, the leaves of typical color, the growth of the current year is normal, the stem without visible damage, pests and diseases are absent.

Woody plants weakened. The crown is thinned, leaves of lighter color, growth of the current year reduced compared to normal, dry shoots present (no more than $1 / 4$ ), stem with minor damage, the impact of pests and diseases is insignificant.

Woody plants are highly weakened. The crown is strongly thinned, leaves of lighter color, the growth of the current year is greatly reduced compared to normal, dry shoots present (from 1/4 to 1/2), stem with significant damage, plant oppressed by pests and diseases.

Decorativeness estimation of individual plant specimens was carried out according to a 4-point system (Frolova, 1994) [15]:

4 points - plants characterized by good growth, crown development and shape, bright and juicy color of leaves and flowers, favorable effect;

3 points - plants that retain their habitus, are in good condition, having a well-formed stem and branches of the crown;

2 points - plants with noticeable inhibition in growth and development, the crown and stem are deformed. There are dry branches and shoots, the stem is damaged (frost-cracks, hollows);

1 point - plants are highly oppressed. Branches die off by $60-70 \%$, the crown is severely deformed, the stem is badly damaged, plants can not restore their vital activity and must be removed.

The bulk of gathered collection are stored in the herbarium named after V.N. Khitrovo, Orel State University named after I.S. Turgenev (OHHI).

\section{Results and Discussion}

The collection of wood-shrubby ornamental plants in the park is represented by row plantings, landscape homogeneous and mixed groups, hedges and solitaires. For perception completeness, the arboretum is designed in a mixed style: both regular and landscape elements of the range are noted.

In the studied area, there are 117 species of wood-shrubby plants belonging to two groups: Gymnospermae (Pinophyta) and Angiospermae (Magnoliophyta). Out of these 117 species, 21 are wild-growing, 96 are introduced.

The Pinophyta group includes 19 species of plants belonging to one class, two families: Pinaceae - 13 species (11.1\%), Cupressaceae are 6 species (5\%). Several gymnosperms genera are represented in the OrelSAU arboretum: Picea and Juniperus 4 species each, Larix and Pinus 3 species each, Abies -2, Chamacyparis and Thuja 1 species each. Some species are represented by several forms. Thus, arborvitae is represented by the following forms: "Danica", "Filiformis", "Brabant", "Aureospicata". 
The group of flowering plants (Magnoliophyta) is represented by 25 families and 98 species (table 1).

Table 1. Families represented in the OrelSAU Arboretum

\begin{tabular}{|c|c|c|}
\hline Family & Number of genera $/ \%$ & $\begin{array}{c}\text { Number of } \\
\text { species/\% }\end{array}$ \\
\hline Aceraceae Lindl. & $1 / 1.6$ & $3 / 2.6$ \\
\hline Anacardiaceae Lindl. & $2 / 3.1$ & $2 / 1.7$ \\
\hline Berberidaceae Juss. & $2 / 3.1$ & $4 / 3.4$ \\
\hline Betulaceae S.F. Gray & $3 / 4.8$ & $5 / 4.3$ \\
\hline Buxaceae Dumort. & $1 / 1.6$ & $1 / 0.8$ \\
\hline Caprifoliaceae Juss. & $2 / 3.1$ & $3 / 2.6$ \\
\hline Celastraceae R. Br. & $1 / 1.6$ & $1 / 0.8$ \\
\hline Cornaceae Dumort. & $1 / 1.6$ & $1 / 0.8$ \\
\hline Cupressaceae F.W. Neger & $3 / 4.8$ & $6 / 5.0$ \\
\hline Elaeagnaceae Juss. & $1 / 1.6$ & $1 / 0.8$ \\
\hline Euphorbiaceae Juss. & $1 / 1.6$ & $1 / 0.8$ \\
\hline Fagaceae Dumort. & $1 / 1.6$ & $2 / 1.7$ \\
\hline Grossulariaceae DC. & $1 / 1.6$ & $1 / 0.8$ \\
\hline Hippocastanaceae DC. & $1 / 1.6$ & $1 / 0.8$ \\
\hline Hydrangeaceae Dumort. & $3 / 4.8$ & $6 / 5.0$ \\
\hline Juglandaceae A. Rich. ex Kunth & $1 / 1.6$ & $1 / 0.8$ \\
\hline Leguminosae Juss. & $3 / 4.8$ & $3 / 2.6$ \\
\hline Oleaceae Hoffmgg. etLink & $3 / 4.8$ & $7 / 6.0$ \\
\hline Pinaceae Lindl. & $5 / 7.8$ & $13 / 11.1$ \\
\hline Rhamnaceae Juss. & $1 / 1.6$ & $1 / 0.8$ \\
\hline Rosaceae Juss. & $20 / 31.7$ & $42 / 36.0$ \\
\hline Salicaceae Mirb. & $1 / 1.6$ & $3 / 2.6$ \\
\hline Sambucaceae BatschexBorkh. & $1 / 1.6$ & $1 / 0.8$ \\
\hline Tamaricaceae Link. & $1 / 1.6$ & $1 / 0.8$ \\
\hline Tiliaceae Juss. & $1 / 1.6$ & $3 / 2.6$ \\
\hline Ulmaceae Mirb. & $1 / 1.6$ & $2 / 1.7$ \\
\hline Viburnaceae Rafin. & $1 / 1.6$ & $2 / 1.7$ \\
\hline Total & $63 / 100.0$ & $117 / 100.0$ \\
\hline
\end{tabular}

Rosaceae family includes the largest number of genera (20). In a systematic aspect, it is a complex family with representatives widely found throughout the Holarctic. The remaining families are represented by a significantly smaller number of genera (Table 1).

The following predominate among genera: Spiraea L. - 7 species, Rosa L. and Crataegus L. - 5 species each, Picea Dietr., Juniperus L., Syringa L. - 4 species each.

According to the number of species, the most numerous is the Rosaceae family - 42 $(36 \%)$. This is due to the fact that representatives of this family have high decorative qualities, 
as well as being medicinal, food, honey crops. Due to this, many species of this family have numerous forms and varieties also widely represented in the dendrological park. For example, they have numerous forms and varieties also widely represented in the dendrological park. For example, varieties Dasiphora fruticosa (L.) Rybd.: "Goldfinger", "Pink Beauty", "Abbotswood"; Spiraea japonica L.: "Albiflora", “Antoni Water", "Goldflame"," Little Princess" etc. Rosaceae species are widely used in landscape construction.

The remaining families represented to a significantly lesser extent: Oleaceae -7 species (6\%), Hydrangeaceae - 6 (5\%), Betulaceae - 5 (4.3\%), Berberidaceae - 4 (3.4\%). The number of families with one species is $11(8.8 \%)$.

Of the species presented in the park by life forms, trees predominate - 57 species, the shrubs include 47 species; 13 species have the vital form of both a tree and a shrub (Figure 1). The first degree trees (more than $20 \mathrm{~m}$ ) predominate, which are most often used in various planting types in landscape construction: row and single plantings, park and boulevard plantations, etc. Second place - low shrubs (up to $2 \mathrm{~m}$ ), which are also widely used in landscaping (alpine rock gardens, solitaires, etc.), allowing to create a variety of compositions.

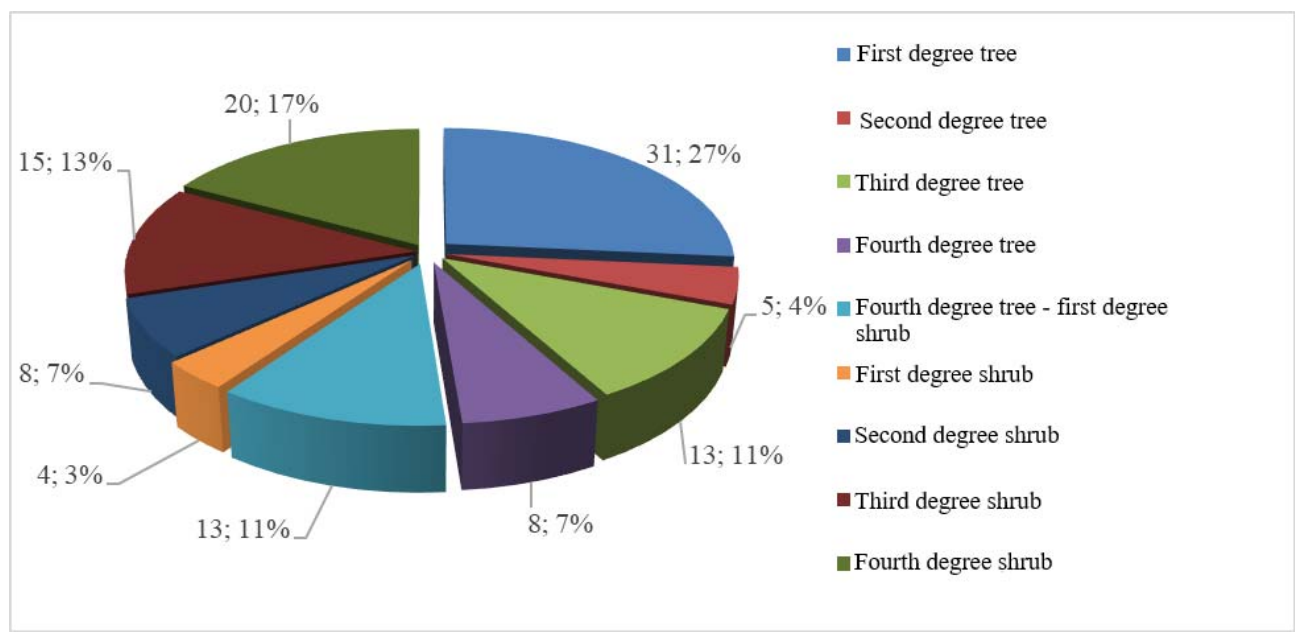

Fig. 1. Biomorph ratio of wood plants in the OrelSAU arboretum.

Only introduced woody plants species of the dendrological park were considered in chorologic analysis. The largest number of species is of North American origin (Figure 2), which is understandable. The climatic conditions of North America are close to that of Eurasia. In addition, the dendrological flora of the North American continent is characterized by woody plants' species diversity. 


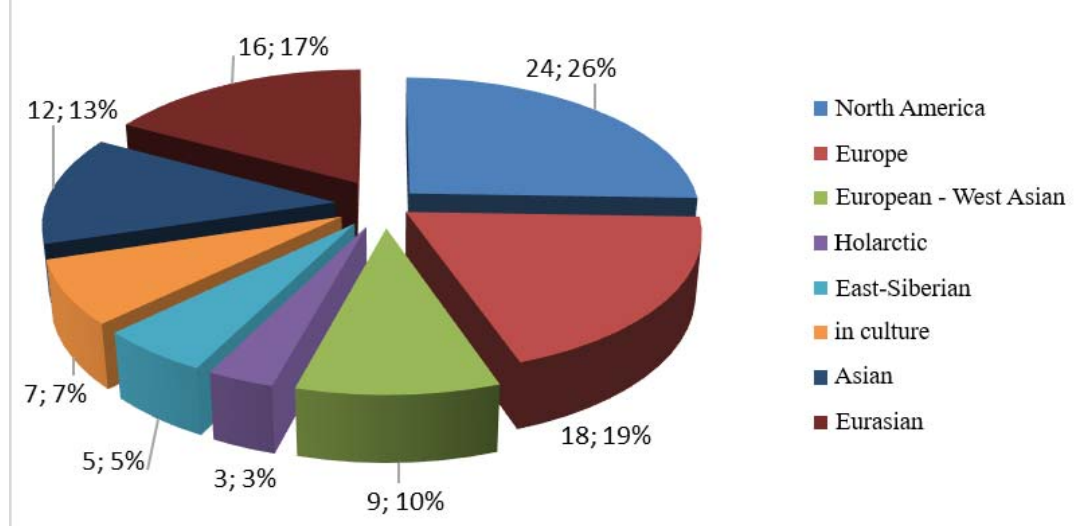

Fig. 2. Areas of natural wood plants' distribution of Orel SAU arboretum.

The second place is occupied by species of the European range - 18. These plants adapt well in the conditions of the Orel region. Among them there are many species with a Southern European range of natural distribution, as well as 9 species of European - West Asian origin. These species quickly adapt to the conditions of the Orel region. First of all, this is due to the introduction of these species' representatives into urbanized conditions. The climate of cities is characterized by higher temperatures - by $1-3^{\circ} \mathrm{C}$ compared to neighboring territories. In addition, in recent years there have been global climate changes towards rising temperatures. It also contributes to better adaptation of plants from more southern regions. The Eurasian range is represented by 16 species. The least represented species are the ones growing throughout the Holarctic. This analysis allows to identify promising species for further introduction.

All wood plants species presented in the arboretum have been successfully adapted to the conditions of Orel (Figure 3). Out of the 96 introduced plants, 9 species have undergone full introduction and show a tendency to invasiveness (1 group of introduction). Such species include Acer negundo L., Amelanchier spicata (Lam.) K. Koch, Aronia mitschurinii Skvorts. et Maitul., Fraxinus pennsylvanica Marchall, Quercus rubra L., Robinia pseudoacacia L., Rosa rugosa Thunb., Sambucus racemosa L., Ulmus pumila L. Aesculus hippocastanum L. and Amorpha fruticosa L. also have annual self-sewing, but it perishes at 2-3 years (1-2 group of introduction). Most species have successfully undergone introduction. They flower well and bear fruits (3 group of introduction). 12 species have an average vitality, i.e. the overall plants' development is slightly weaker, the growth of shoots, foilage, flowering and fruiting do not reach maximum (3 group of introduction). Such species include Amygdalus triloba (Lindl.) Rick., Armeniaca vulgaris Lam., Kerria japonica (L.) DC. etc. (3 introduction group). For 2 species, additional care is required - shelter for the winter, without which they die (4 group of introduction) (Figure 3). 


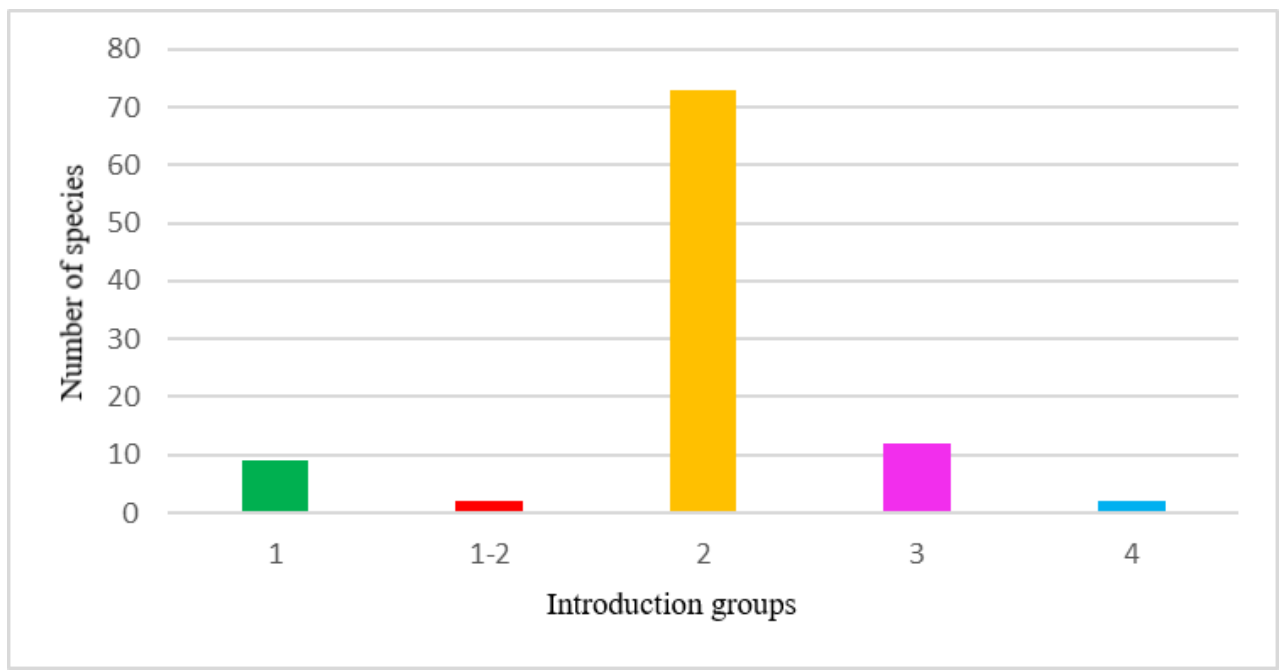

Fig. 3. Number of species by introduction groups [13].

Separate studies were carried out on species' winter resistance (Figure 4). Most of the species $(86 ; 87.5 \%)$ have a high winter resistance degree, there are no damage to annual shoots in winter ( 1 group of winter resistance). In some years, 4 species had little damage to annual shoots (1-2 group of winter resistance). In 6 species, annual shoots are damaged annually (2 group of winter resistance).

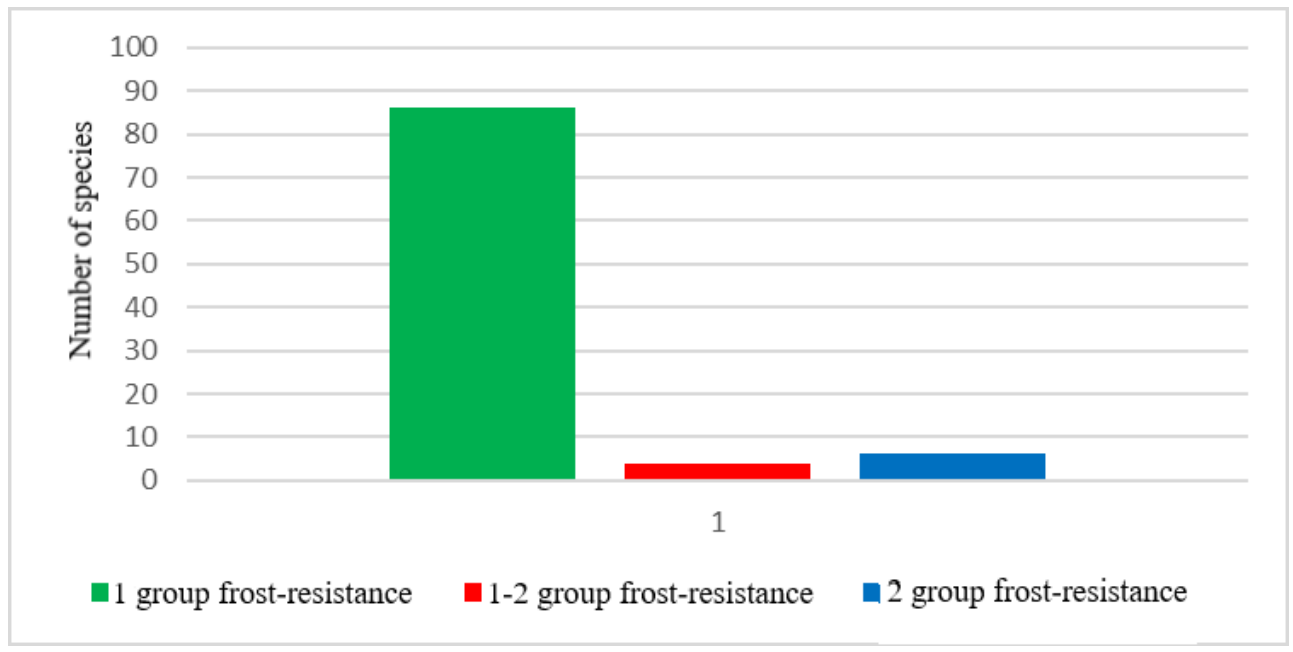

Fig. 4. Number of species by winter resistance groups.

An assessment of the decorativeness and sanitary condition of wood plantations was also carried out.

The plantings' decorativeness is an important aspect in the aesthetic appearance formation of the urban environment. The higher the decorative plants' qualities, the more expressive and attractive is the architectural-artistic appearance of the landscape architecture object. The evaluation was carried out visually, and given the fact that plants are capable of significant appearance changes throughout the season, aesthetic evaluation should be regular.

On the territory of the Orel SAU Arboretum, 247 (4.7\%) growing plants are marked with oppression in growth and development, the crown and stem are deformed, there are dry 
branches and shoots, the stem is damaged (frost-cracks, hollows) (2 points); 462 (8.8\%) plants retaining their habitus in good condition have a well-formed stem and crown branches (3 points); 4,545 (86.5\%) plants that are marked by good growth, development and shape of the crown, originality of its structure, bright and juicy color of leaves and flowers, favorable emotional impact (4 points, the highest score). The average wood plantations decorativeness estimate was 3.5 .

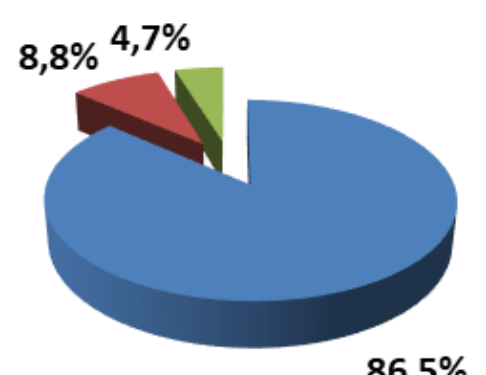

4 points

3 points

2 points

$86,5 \%$

Fig. 5. Evaluation of wood plants decorativeness in Orel SAU arboretum.

It should be noted that there are no strongly oppressed plants in the arboretum (branches die off by $60-70 \%$, the crown is severely deformed, the stem is badly damaged, plants can not restore their vital activity and should be removed). This and a small number of plants that received a score of 2 characterizes the territory where agrotechnical care for plants is proper and timely.

Evaluation of wood plantations' sanitary condition in the Orel SAU Arboretum allows to say that most species are stable in urban environments (62.7\% - without signs of weakening). They have a thick crown, leaves of typical color, the growth of the current year is normal, the stem has no visible damage, pests and diseases are absent. Weakened plants make up $30.1 \%$. They are characterized by the following traits: the crown is thinned, leaves of lighter color, the growth of the current year is reduced compared to normal, there are dry shoots (no more than 1/4), stem with minor damage, the influence of pests and diseases is insignificant. $7.2 \%$ - significantly weakened plants: the crown is strongly thinned, leaves of lighter color, the growth of the current year is strongly reduced compared to normal, there are dry shoots (from $1 / 4$ to $1 / 2$ ), stem with significant damage, the plant is oppressed by pests and diseases.

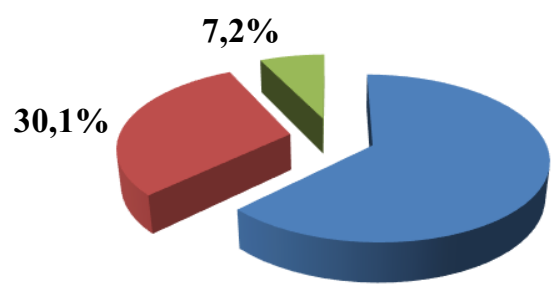

good condition

weakened condition

$62,7 \%$

strongly weakened condition

Fig. 6. Sanitary condition of wood plants in the Orel SAU arboretum.

A practical recommendation for oppressed plants is the fight against leaf miner on chestnuts and emerald ash borer on ashes, significantly reducing decorative quality of species. This is achieved by either chemical pest control or the complete removal of trees from the territory. Trees in good condition ( 3 and 4 points) need constant agrotechnical care and periodic sanitary and shaping pruning. 
It should be noted that plantings in the arboretum are planted in such a way that starting from early spring (forsythia, willow) and up to August (snowberry, securinega, tormentil), flowering is observed in sections. At the same time, when late-flowering plants are just beginning to bloom or are at the peak of flowering, some species are already beginning to acquire the autumn color of the leaves, which also helps to increase appearance decorativeness of the park. A large number of various conifers - spruce, pine, cedar, juniper, cypress - Undoubtedly give picturesqueness and decorativeness to the landscape of the park all year round.

Based on the conducted studies, 12 species of wood-shrub plants are recommended for widespread use in landscape construction: Abies balsamea (L.) Mill., Pinus cembra L., Juniperus virginiana L., Chamaecyparis pisifera (Siebold \& Zucc.) Endl., Corylus colurna L., Philadelphia pubescens Loisel., Deutzia scabra Thunb., Rubus odoratus L., Armeniaca manshurica (Maxim.) Skvorts., Padus maackii (Rupr.) Kom., Sotinus coggygria Scop., Ligustrina amurensis Rupr. They underwent full introduction, but do not show a tendency to invasiveness, are characterized by a high degree of winter resistance, stable in urbanized conditions and very decorative [16-21]. Some species can be used in single or row plantings, such as Abies balsamea (L.) Mill., some in solitaires, such as Deutzia scabra Thunb., or hedges, such as Juniperus virginiana L.

\section{Conclusions}

1. 117 species of woody plants grow in the dendrological park of the Orel SAU, of which 21 are wild growing and 96 are introduced.

2. The woody plants represented in the arboretum are dominated by trees -57 species, shrubs - 47 species, 13 species can take both the form of a small tree and a shrub.

3. The most represented species are from North America -31 species (26\%), the least - with a holarctic distribution range of 3 species (3\%).

4. Most species growing in the Orel SAU Arboretum successfully underwent introduction - 75 species, 9 species show a tendency to invasiveness, 86 species have a high degree of winter resistance.

5. An assessment of woody plantings' sanitary condition indicates that most of the park's plantings are in good and satisfactory sanitary condition, and the high decorativeness rating in most species (average decorativeness score of 3.5) allows plants to perform all their ecological, aesthetic and sanitary and hygienic functions in the urban environment.

6. Twelve species of woody plants are recommended for widespread use in urban landscape construction.

\section{References}

1. Yu. Dubovitskaya, E.V. Zolotareva, Beautiful flowering trees and shrubs of the Orel SAU arboretum, 162 (2009)

2. Geography of the Orel region,10-97 (2004)

3. Weather and climate, Orel. http://www.pogodaiklimat.ru/climate/27906.htm [date of request 8.02.2021]

4. T.N. Valyagina-Malyutina, Trees and shrubs of the middle zone of the European part of Russia: the determinant, 112 (1998)

5. T.N. Vstovskaya, I.Yu. Koropachinsky, Determinant of local and exotic woody plants of Siberia, 701 (2003)

6. Trees and shrubs of the USSR, 1-6, (1949-1962) 
7. A.L. Budantsev, G.P. Yakovlev, Illustrated Manual of plants of the Leningrad region, 799 (2006)

8. P.F. Maevsky, Flora of the middle zone of the European part of Russia, 635 (2014)

9. Flora of Eastern Europe, 9-11 (1996-2005)

10. Elis Thomas S. North American trees: determinant, 958 (2014)

11. S.Ya. Sokolov, O.A. Svyazev, Geography of woody plants of the USSR, 265 (1965)

A. G. Golovach, Trees, shrubs and lianas of the Botanical Garden of the BIN of the USSR, 188 (1980)

12. E.A. Parakhina, Trees and shrubs of the Orel region: wild and introduced, 466 (2011)

13. S.L. Rysin, N.A. Trusov, I.O. Yatsenko, Features of the organization of monitoring of valuable woody plants in urbanized territories, 5, 140-144 (2015)

14. V.A. Frolova, Evaluation of aesthetic advantages of natural landscapes, 5, 27-33 (1994)

15. Richard Coles, Sandra Costa, Landscape and Urban Planning, 170, 1-5 (2018) doi.org/10.1016/j.landurbplan.2017.10.003

16. Deni Ruggeri, Deven Young, Frontiers of Architectural Research, 5, 15-26 (2016) doi.org/10.1016/j.foar.2015.12.001

17. Ryan M. Perkl, Landscape, Urban Planning, 156, 44-58 (2016) doi.org/10.1016/j.landurbplan.2016.05.016

18. Alamah Misni, Procedia - Social and Behavioral Sciences, 22223, 693-701 (2016) doi.org/10.1016/j.apcbee.2014.10.058

19. Julien Carlier, James Moran, Journal of Environmental Management, 2471, 790-803 (2019) doi.org/10.1016/j.jenvman.2019.06.116

20. Nathan L. Haan, Yajun Zhang, Douglas A. Landis, Trends in Ecology \& Evolution, 35, 175-186 (2020) doi.org/10.1016/j.tree.2019.10.003 